\title{
FORMULATION AND EVALUATION OF FAMOTIDINE FAST DISSOLVING TABLETS USING SYNTHETIC SUPERDISINTEGRANTS
}

\author{
SARIPILLI RAJESWARI ${ }^{*}$, M. YERNI KUMARI ${ }^{1}$
}

${ }^{1}$ Affiliated to Andhra University, Maharajah's College of Pharmacy, Phool Baugh, Vizainagaram 535002, India

Email: rajeswarimalli@gmail.com

Received: 21 Mar 2019 Revised and Accepted: 21 Jun 2019

\section{ABSTRACT}

Objective: The main aim of the present research work was to formulate fast dissolving tablets of famotidine by direct compression method and to evaluate the effect of synthetic super disintegrating agent on drug release pattern.

Methods: The fast dissolving tablets were prepared by using crospovidone, croscarmellose sodium, sodium starch glycolate as superdisintegrants $(2,4$ and $6 \% \mathrm{w} / \mathrm{w})$, mannitol $20 \%$ and microcrystalline cellulose $(44,46$ and $48 \% \mathrm{w} / \mathrm{w})$ as a directly compressible vehicle. All the prepared tablets were evaluated for hardness, friability, drug content uniformity, weight variation, disintegrating time, wetting time and in vitro drug release studies.

Results: All the prepared fast dissolving tablets formulations were within the Pharmacopoeial standards limits. Based on in vitro drug release studies ( $>90 \%$ within $30 \mathrm{~min}$ ), the optimised formulations were optimised tested for the short term stability (at $40{ }^{\circ} \mathrm{C} / 75 \% \mathrm{RH}$ for $3 \mathrm{mo}$ ) and drug excipient interaction (fourier transform infrared spectroscopy).

Conclusion: Hence, formulation prepared with $6 \% \mathrm{w} / \mathrm{w}$ of crosspovidine and $44 \% \mathrm{w} / \mathrm{w}$ of microcrystalline cellulose as emerged as the overall best formulation ( $>90 \%$ within $30 \mathrm{~min}$ ) compared to marketed product ( $>70 \%$ within $30 \mathrm{~min}$ ). Short-term stability studies on the formulations indicated that there are no significant changes in drug content and in vitro drug release $(\mathrm{p}<0.05)$

Keywords Famotidine, Croscarmellose sodium, Crosspovidine, Sodium starch Glycolate, Fast dissolving tablets

(C) 2019 The Authors. Published by Innovare Academic Sciences Pvt Ltd. This is an open access article under the CC BY license (http://creativecommons.org/licenses/by/4.0/] DOI: http://dx.doi.org/10.22159/ijpps.2019v11i8.33175

\section{INTRODUCTION}

Oral routes of drug administration is the most popular route for systemic effects due to its ease of ingestion, pain, avoidance, versatility and most importantly patient compliance. As solid formulations do not require any sterile conditions they are less expensive [1]. Famotidine is a propanimidamide and histamine $\mathrm{H} 2$ receptor antagonist with antacid activity. As a competitive inhibitor of histamine $\mathrm{H} 2$-receptors located on the basolateral membrane of the parietal cell, famotidine reduces basal and nocturnal gastric acid secretion, resulting in a reduction in gastric volume, acidity, and amount of gastric acid released in response to various stimuli. The drug is $40-45 \%$ absorbed orally but it undergoes minimal metabolism on first pass through the liver. Famotidine is metabolized in the liver to famotidine S-oxide (S-famotidine). They also inhibit gastric acid secretion stimulated by food, betazole, pentagastrin, caffeine, insulin and physiological vagal reflex. Famotidine is used in the treatment of peptic ulcer disease and gastroesophageal reflux disease [2-4]. Thus, famotidine is better option for the development of immediate release tablets [5, 6]. The purpose of the present research work was to develop and characterize immediate release tablets of famotidine using various synthetic superdisintegrants such as crospovidone (CP), croscarmellose sodium (CCS), sodium starch glycolate (SSG) with mannitol to release the medicament and mask bitter taste [7-9]. Fasting dissolving tablets (FDTs) helps in immediate release of medicament, leading to an increase in bioavailability of the drug and quick onset of pharmacological action can take place [10-14].

\section{MATERIALS AND METHODS}

\section{Materials}

Famotidine, crospovidone, croscarmellose sodium and sodium starch glycolate were purchased from Yarrow chem. product, Mumbai, India. Mannitol was purchased from Fisher scientific laboratory, Andhra Pradesh, India. Microcrystalline cellulose was purchased from Chemica-biochemica reagents, Mumbai, India. All other reagents and chemicals were of analytical grade.

Table 1: Formulation of famotidine fast dissolving tablets

\begin{tabular}{|c|c|c|c|c|c|c|c|c|c|c|}
\hline S. No. & Ingredients (mg) & F1 & F2 & F3 & F4 & F5 & F6 & F7 & F8 & F9 \\
\hline 1. & Famotidine & 20 & 20 & 20 & 20 & 20 & 20 & 20 & 20 & 20 \\
\hline 2. & Sodium starch glycolate & 4 & 8 & 12 & - & - & - & - & - & - \\
\hline 3. & Croscarmellose sodium & - & - & - & 4 & 8 & 12 & - & - & - \\
\hline 4. & Crospovidone & - & - & - & - & - & - & 4 & 8 & 12 \\
\hline 5. & Mannitol & 20 & 20 & 20 & 20 & 20 & 20 & 20 & 20 & 20 \\
\hline 6. & Microcrystalline cellulose & 51 & 47 & 43 & 51 & 47 & 43 & 51 & 47 & 43 \\
\hline \multirow[t]{2}{*}{7.} & Magnesium stearate & 5 & 5 & 5 & 5 & 5 & 5 & 5 & 5 & 5 \\
\hline & Total weight & 100 & 100 & 100 & 100 & 100 & 100 & 100 & 100 & 100 \\
\hline
\end{tabular}

\section{Methods}

Preparation of famotidine FDTs

Each tablet containing $20 \mathrm{mg}$ famotidine were prepared by using direct compression method with 50 tablets for batch. The compositions of various formulations of the tablets with F1 to F9 were listed in table 1. For preparation of powder blend, pure drug famotidine and superdisintegrants SSG, CCS and CP were passed through sieve No. 40 \# and mixed well for $10 \mathrm{~min}$ in a glass motor and pestle. To the above add microcrystalline cellulose after passing 
through sieve No. 40 \# and blended thoroughly for 5 min to make powdered blend. This powder was lubricated with sufficient amount of magnesium stearate after passing through sieve No. 80 \# [15]. All the materials were directly compressible so this uniformly mixed blend was compressed into tablets of $100 \mathrm{mg}$ weight on 12 station tablet compression machine (Rimek tablet MINI press, karnavathi engineering Pvt. Ltd. Gujarat, India) using $8 \mathrm{~mm}$ flat round punches with $2-4 \mathrm{~kg} / \mathrm{cm}^{2}$ hardness.

\section{Evaluations}

\section{Evaluation of pre-compression parameters}

Pre-compression parameters such as angle of repose, bulk density and tap density, Carr's compressibility index and Hausner's ratio were determined $[16,17]$.

\section{Angle of repose}

It was determined by funnel method. The frictional forces in a loose powder or granules can be measured by angle of repose. This is the maximum angle possible between the surface of a pile of powder or granules and the horizontal plane. The powder was allowed to flow through the funnel fixed to a stand at definite height. The angle of repose $(\theta)$ was calculated by measuring the height $(h)$ and radius ${ }^{\circledR}$ of the heap of granules, using Eq. 1.

$$
\theta=\tan ^{-1}\left[\frac{h}{r}\right] \ldots \ldots \ldots . . . \text { Eq. } 1
$$

\section{Bulk density}

The bulk density was determined by pouring the blend into a graduated cylinder of density apparatus. The bulk volume $\left(\mathrm{V}_{0}\right)$ and the weight of powder $(M)$ were determined. The bulk density $\left(\rho_{0}\right)$ can be calculated using the formula given in Eq. 2.

$$
\text { Bulk density }\left(\rho_{0}\right)=\frac{M}{V_{0}} \ldots \ldots \ldots \ldots \ldots \ldots . . . . . .2
$$

\section{Tapped density}

The bulk density apparatus was allowed to tap for a fixed time. The minimum volume required in the cylinder $\left(\mathrm{V}_{\mathrm{f}}\right)$ and weight of the blend $(M)$ were obtained. The tapped density $\left(\rho_{\mathrm{f}}\right)$ can be calculated using the formula given in Eq. 3.

$$
\text { Tapped density }=\frac{M}{V_{f}}
$$

\section{Carr's compressibility index}

The flow ability of powder can be evaluated by comparing the bulk density and tapped density of powder and the rate at which it packed down. The Carr's compressibility index is calculated by using the Eq. 4 .

$$
\% \text { compressibility index }=\frac{\rho_{t}-\rho_{0}}{\rho_{t}} \times 100
$$

\section{Hausner's ratio}

It is an indirect index of easy of powder flow. It is calculated by using Eq.5.

$$
\text { Hausner's ratio }^{\prime}=\frac{\rho_{t}}{\rho_{0}} \quad \text {............. Eq. } 5
$$

\section{Compatibility studies}

The compatibility studies were performed using fourier transform infrared spectroscopy (FTIR), differential scanning calorimetric studies (DSC), X-ray diffraction studies (XRD) and scanning electron microscope (SEM).

\section{Evaluation of post-compression parameters}

Post-compression parameters such as weight variation, thickness, hardness, friability, water absorption ratio, wetting time, disintegration test, in vitro dispersion time, content uniformity and in vitro dissolution study were determined.

\section{Weight variation}

Randomly 20 tablets were taken from each batch and their weight was determined individually and collectively on a digital weighing balance. The average weight of the tablet was determined from the collective weights [18].

\section{Thickness}

Randomly 10 tablets from each formulation were taken and their thickness was measured using a Vernier callipers and the reading was recorded in millimetres [19].

\section{Hardness}

Three tablets were randomly picked from each formulation batch and the mean and standard values were calculated [19]. Hardness of the tablet was determined using the Monsanto hardness tester and expressed in $\mathrm{kg} / \mathrm{cm}^{2}$.

\section{Friability}

A sample of whole tablets corresponding to about $6.5 \mathrm{~g}$ was weighed and the initial weight was recorded $\left(\mathrm{W}_{0}\right)$ and placed in Roche friabilator and rotated at the speed of $25 \mathrm{rpm}$ for 100 revolutions [15]. Then tablets were removed from the friabilator, dusted off the fines and again weighed and the final weight was recorded $\left(\mathrm{W}_{\mathrm{f}}\right)$. Percentage friability was calculated by using the formula given in Eq. 6 .

$$
\% \text { Friability }=\left[\frac{W_{o}-W_{f}}{W_{o}}\right] X 100 \text {. }
$$
Eq. 6

\section{Wetting time and water absorption ratio}

A piece of tissue paper folded twice and placed in small petri dish containing $10 \mathrm{ml}$ of water. Initially tablet was weighed $\left(\mathrm{W}_{\mathrm{b}}\right)$, placed on the paper and time for complete wetting was measured as wetting time [19]. The wetted tablet was weighted $\left(\mathrm{W}_{\mathrm{a}}\right)$. Water absorption ratio, R, was calculated using the formula given in Eq. 7 .

$$
R=\left[\frac{W_{a}-W_{b}}{W_{b}}\right] \times 100
$$

\section{Disintegration test}

The disintegration time was performed using USP disintegration test apparatus with $0.1 \mathrm{~N} \mathrm{HCl}$ medium at $37 \pm 0.5^{\circ} \mathrm{C}$. A tablet was placed in each of six tubes of apparatus and one disc was added to each tube. The time was recorded when all the fragments of the disintegrated tablet ( 6 tablets) passed through the screen of the basket [18].

\section{Content uniformity}

The drug content was determined by taking 10 dosage units at random and powdered. The blend equivalent to $20 \mathrm{mg}$ of famotidine was weighed and dissolved in $100 \mathrm{ml}$ of $0.1 \mathrm{~N} \mathrm{HCl}$ solution, stirred for $15 \mathrm{~min}$ and filtered. Absorbance was measured at $265 \mathrm{~nm}$ using a UV-Visible double beam spectrophotometer (Cary 60, Agilent technologies, Germany) [5].

\section{In vitro dissolution studies}

In vitro dissolution studies of famotidine were performed in USP XXIII dissolution testing apparatus II (paddle type). The dissolution test was

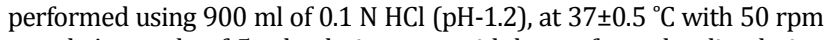
speed. A sample of $5 \mathrm{ml}$ solution was withdrawn from the dissolution apparatus at 5, 10, 15, 30, 45 and 60 min respectively and replaced with $5 \mathrm{ml}$ of fresh dissolution medium. The samples were filtered through Whatmann filter paper (No. 41, Ash less circles $150 \mathrm{~mm}$ ) and measured after suitable dilutions using spectrophotometrically at $265 \mathrm{~nm}$. All the dissolution tests were carried out in triplicates. Cumulative percentage of drug release was drug release was calculated using an equation obtained from a standard curve [5].

\section{Statistical analysis}

All the values are expressed as mean \pm standard deviation (SD). The $t-$ test was used to study the significznce differnce between the control and test at $0.05 \%$ of level of significance. All the values are represented in three determinents. The value less than 0.05 was taken as no significance difference. 


\section{RESULTS AND DISCUSSION}

In the present investigation, FDT of famotidine were prepared by using synthetic superdisintegrants such as crosspovidone, cross carmellose sodium and sodium starch glycolate.

\section{Identification of pure drug}

Physical characterization studies stated that famotidine is white to pale yellow crystalline powder with bitter taste. The melting point of famotidine was found to be in the range of $162-164{ }^{\circ} \mathrm{C}$ when tested using capillary method in melting point apparatus in triplicate, which complies with the standard values in the official monograph as per USPNF. It was found that famotidine is practically insoluble in water, but soluble in organic solvents like acetone, glacial acetic acid.

Identification of the drug was done from absorption maxima, IR and DCS studies. Absorption maxima of $265 \mathrm{~nm}$ confirmed that the drug was pure famotidine as it was previously mentioned in associated literature [5]. The spectra were recorded for pure drug famotidine shown in fig. 1.

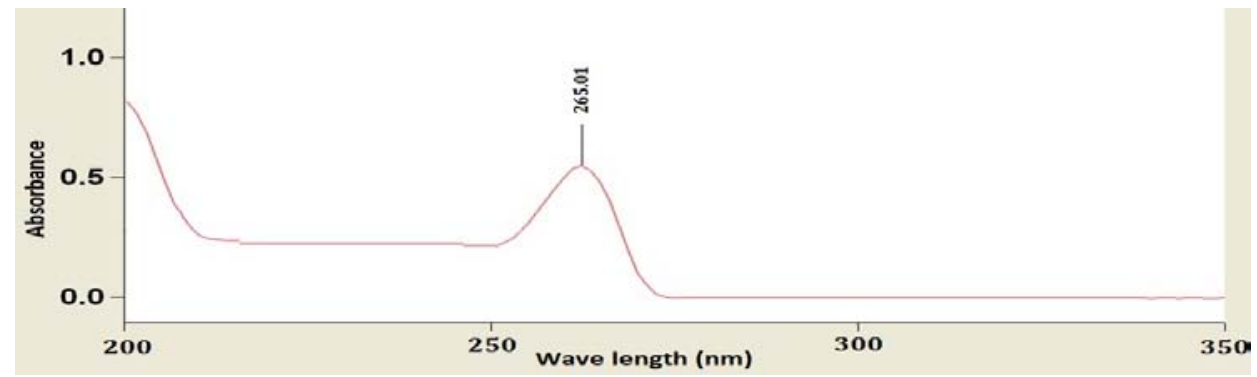

Fig. 1: Spectrometric graph of famotidine pure drug
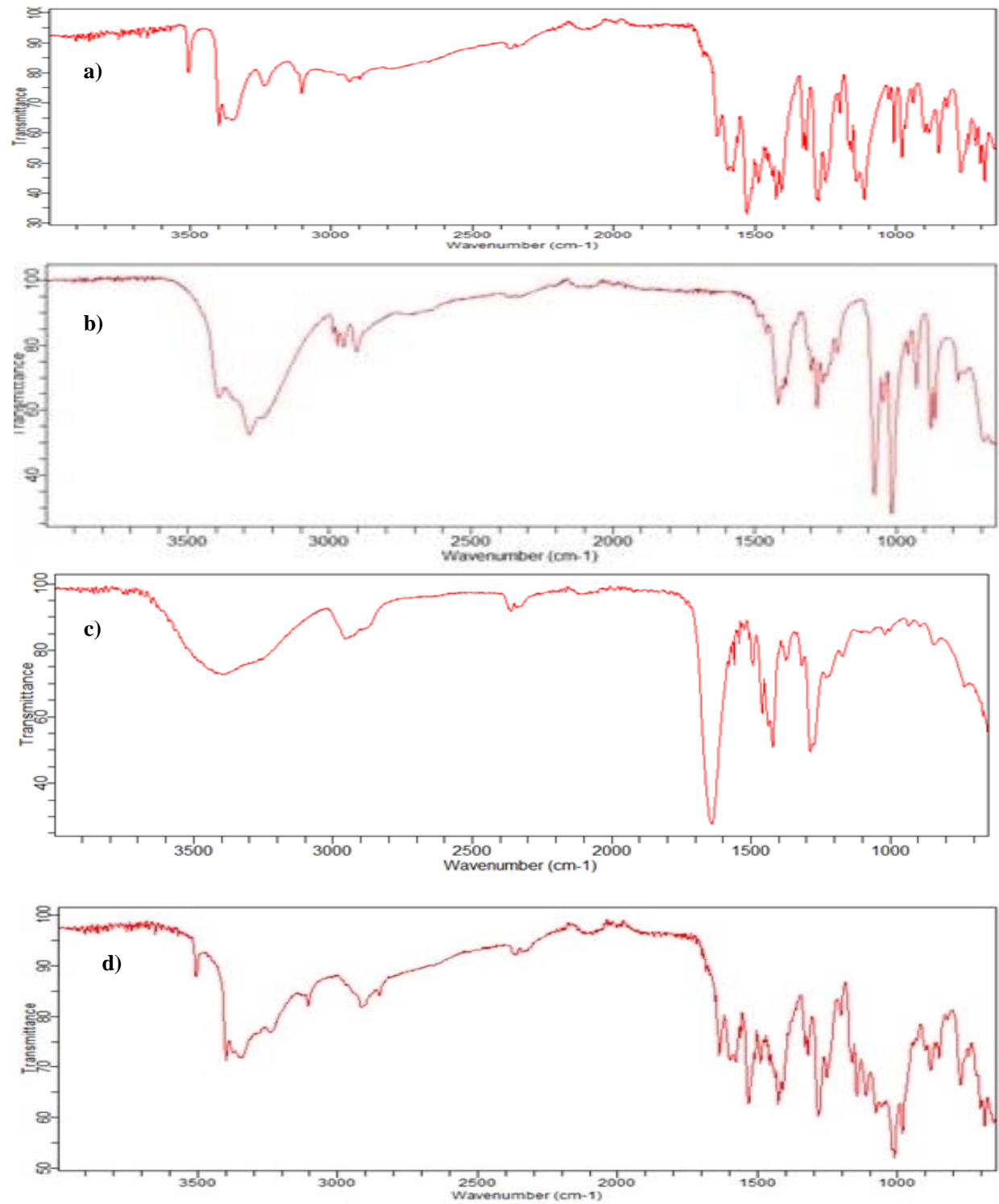

Fig. 2: FTIR Spectrum of a) Famotidine, b) Mannitol, c) Crosspovidine and d) Optimised formulation F8 containing $8 \%$ of crosspovidine 


\section{Fourier transform infrared spectroscopy}

Drug polymer interaction was studied by FTIR analysis. The FTIR spectra of the pure drug famotidine, mannitol, crosspovidone and optimised formulation F8 were shown in the fig. 2. The FTIR spectrum of pure drug showed a characteristic peak of alcohol $(\mathrm{OH})$ stretching vibration at $3400 \mathrm{~cm}^{-1}$ and alkynes stretching vibration at $3300 \mathrm{~cm}^{-1}$. An asymmetric stretching peak at $2100 \mathrm{~cm}^{-1}$ and symmetric stretching peak at $1600 \mathrm{~cm}^{-1}$ indicating the drug was pure. The FTIR spectrum of mannitol showed absorption band nearly at $3300 \mathrm{~cm}^{-1}(\mathrm{~N}-\mathrm{H}), 2800 \mathrm{~cm}$ ${ }^{1}(\mathrm{C}-\mathrm{H})$ and $1400 \mathrm{~cm}^{-1}(\mathrm{C}=\mathrm{C})$ stretching vibration. The FTIR spectrum of crosspovidone showed absorption band nearly at $3400 \mathrm{~cm}^{-1}(\mathrm{OH})$, $2900 \mathrm{~cm}^{-1}(\mathrm{C}=0)$ and $1300 \mathrm{~cm}^{-1}(\mathrm{C}=\mathrm{C})$ stretching vibration. The same peaks were reported in the optimised formulation F8 containing $8 \%$ of crosspovidone and mannitol. There was no change or shifting of characteristic peaks of famotidine tablets, suggested that there was no significant drug polymer interaction which indicates the stable nature of drug inside the formulation.

\section{Differential scanning calorimetric studies}

The DSC thermograph of pure famotidine, mannitol, crosspovidone and optimised formulations F8 shown in fig. 3. The DSC thermograph of famotidine showed a sharp endothermic peak at $163.8{ }^{\circ} \mathrm{C}$ due to melting point of the drug with the enthalpy value of $34.1 \mathrm{~mJ} / \mathrm{mg}$. This shows that the drug considered for the research is in pure form. The melting peak of optimised formulation F8 was shifted to $164.1^{\circ} \mathrm{C}$ with $16.49 \mathrm{~mJ} / \mathrm{mg}$ enthalpy value. The change in melting endotherm of drug may be due to mixing process which lowers purity of each component, it could be concluded that drug was in amorphous state.
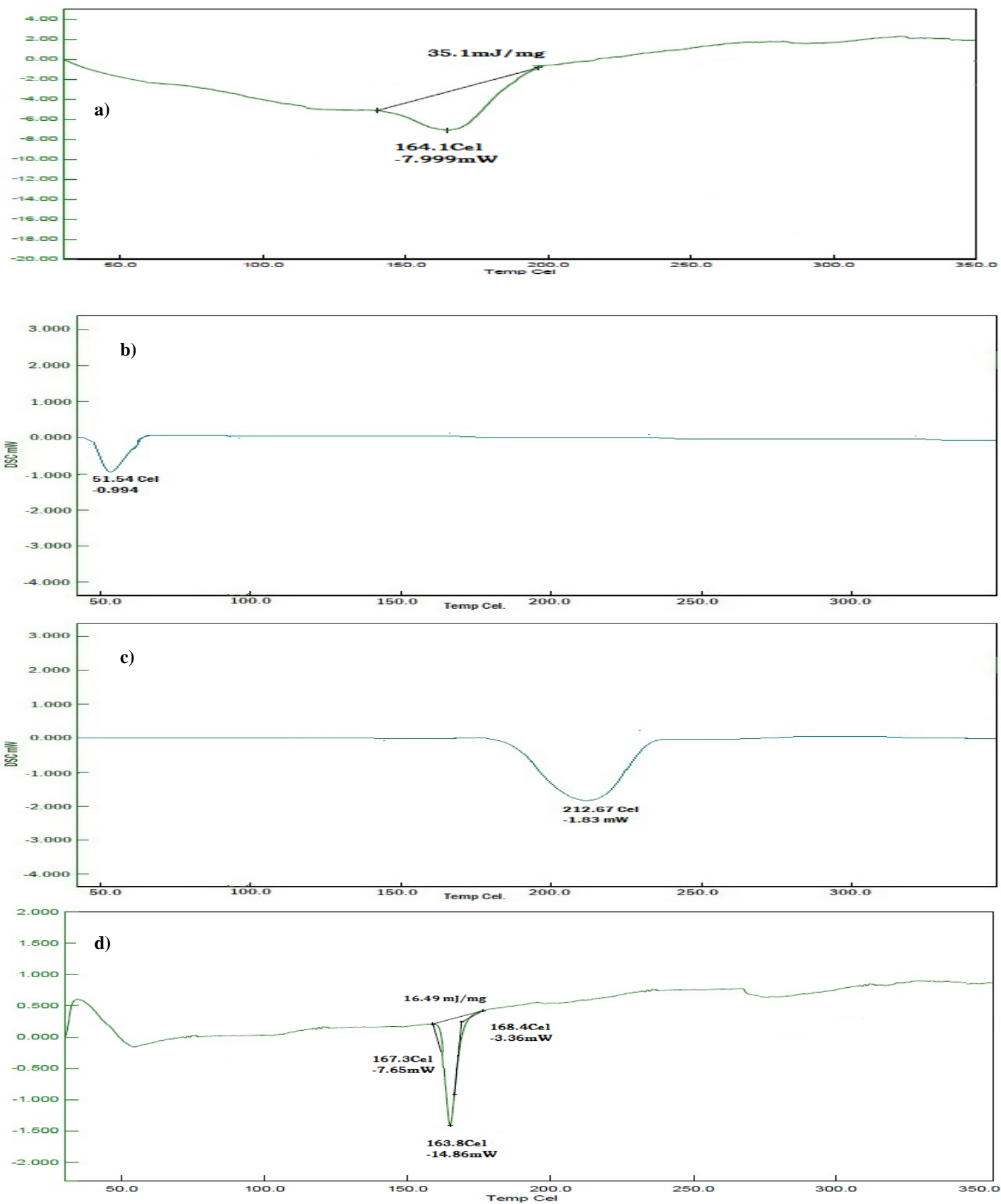

Fig. 3: DSC thermogram of a) Famotidine, b)Mannitol, c) Crosspovidone and d) Optimised formulation F8 containing $8 \%$ of crosspovidone 


\section{XRD studies}

The XRD pattern of famotidine, mannitol, crosspovidone, optimised formulations F8 were shown in fig. 4. The XRD pattern of famotidine showed characteristic sharp intensity diffraction peaks at $2 \theta$ equivalent to $11.39^{\circ}, 15.49^{\circ}, 17.63^{\circ}, 20.65^{\circ}, 23.70^{\circ}$ and $31.9^{\circ}$ which reflects the crystalline nature of drug. The XRD diffractogram of the optimised formulation F8 with $8 \%$ CP showed reduction in peak intensity when compared to the famotidine which was negligible. The results showed that the formulation F8 converted the drug which is a strong crystal habit into a totally amorpous one and was supported by DSC. As a result of amorphisation and substantial increase in surface area, drug particles acquired high internal energy necessary for their enhancing the dissolution of tablets.
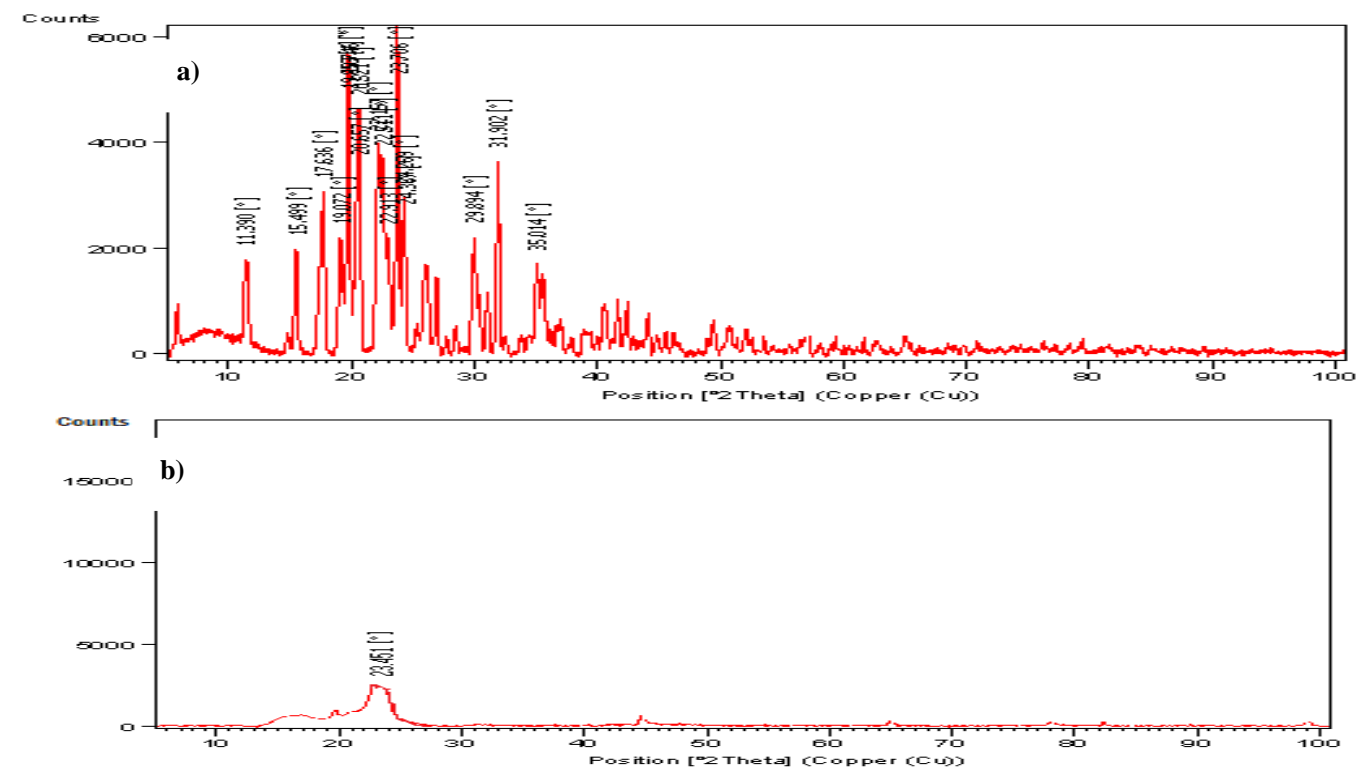

counts

c)
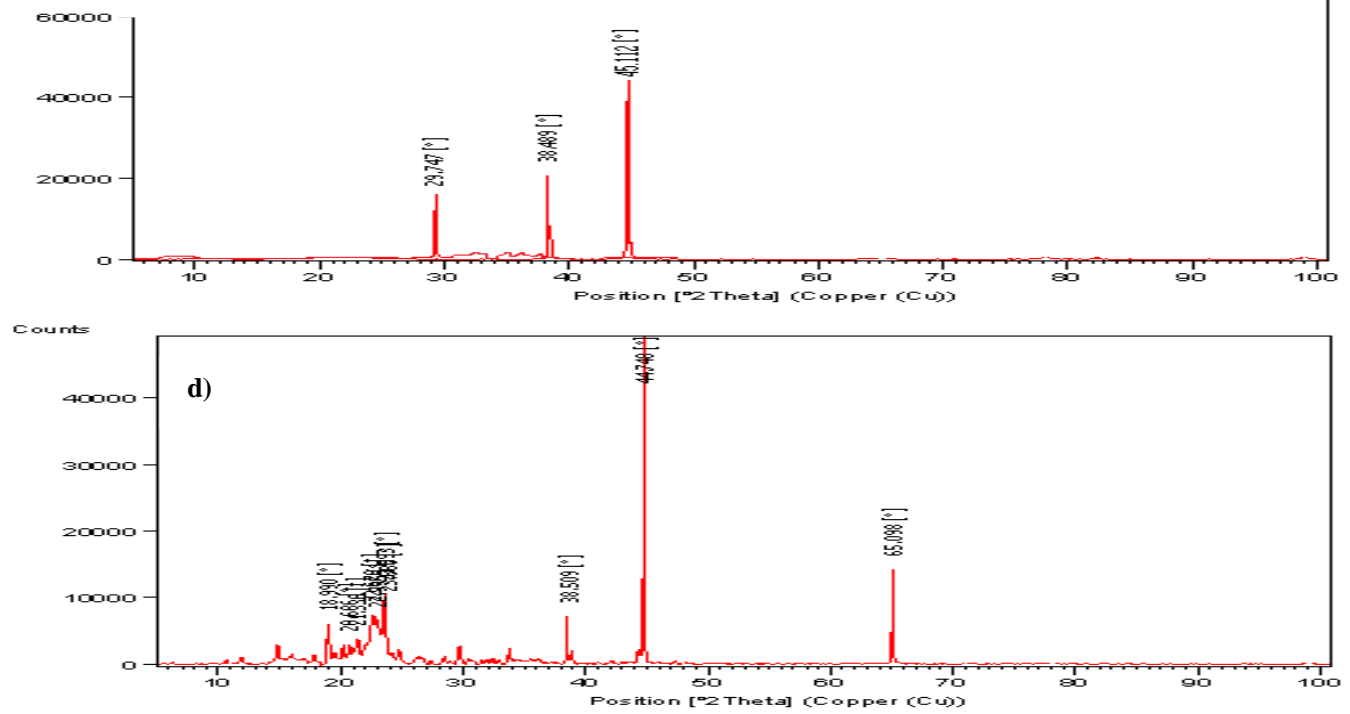

Fig. 4: XRD studies of a) Famotidine, b)Mannitol, c) Crosspovidone and d) Optimised formulation F8 containing $8 \%$ of crosspovidone

\section{SEM analysis}

The SEM analysis of famotidine, mannitol, crosspovidone, optimised formulations F8 shown in fig. 5. The microphotograph of famotidine showed shaped crystalline structure. In the optimised formulations FR4 and FR8, the crystallinity of the drug was lost that indicate the molecular mixing of the drug with CCS and fenugreek seed mucilage powder.

\section{Evaluation of pre-compression studies}

Direct compression technique was used for the preparation of the FDT. Flow characteristics of the material being compressed are important parameters and hence studies were undertaken for the evaluation of flow characteristics of the lubricated blend used in the present study. The results of flow properties of the prepared lubricated blends are shown in table 2 . As the angle of repose values were within the range of $21.08^{\circ}$ to $27.15^{\circ}$ for $\mathrm{F} 1$ to $\mathrm{F} 9$ formulations respectively, which indicates excellent to good flow properties. The compressibility index of all the formulations were within the range of $11.17-14.56 \%$ respectively, with good compressibility index as all the values are within $15 \%$ results in good to excellent flow properties and which describes the frictional and cohesive interactions of the polymers in the formulation. Hausner's ratio of all the formulations was in the range of 1.12 to 1.24 which indicated good flow characteristics for the prepared lubricated blends, as all the values are $<1.25$ indicating the polymers with low interparticle friction. 

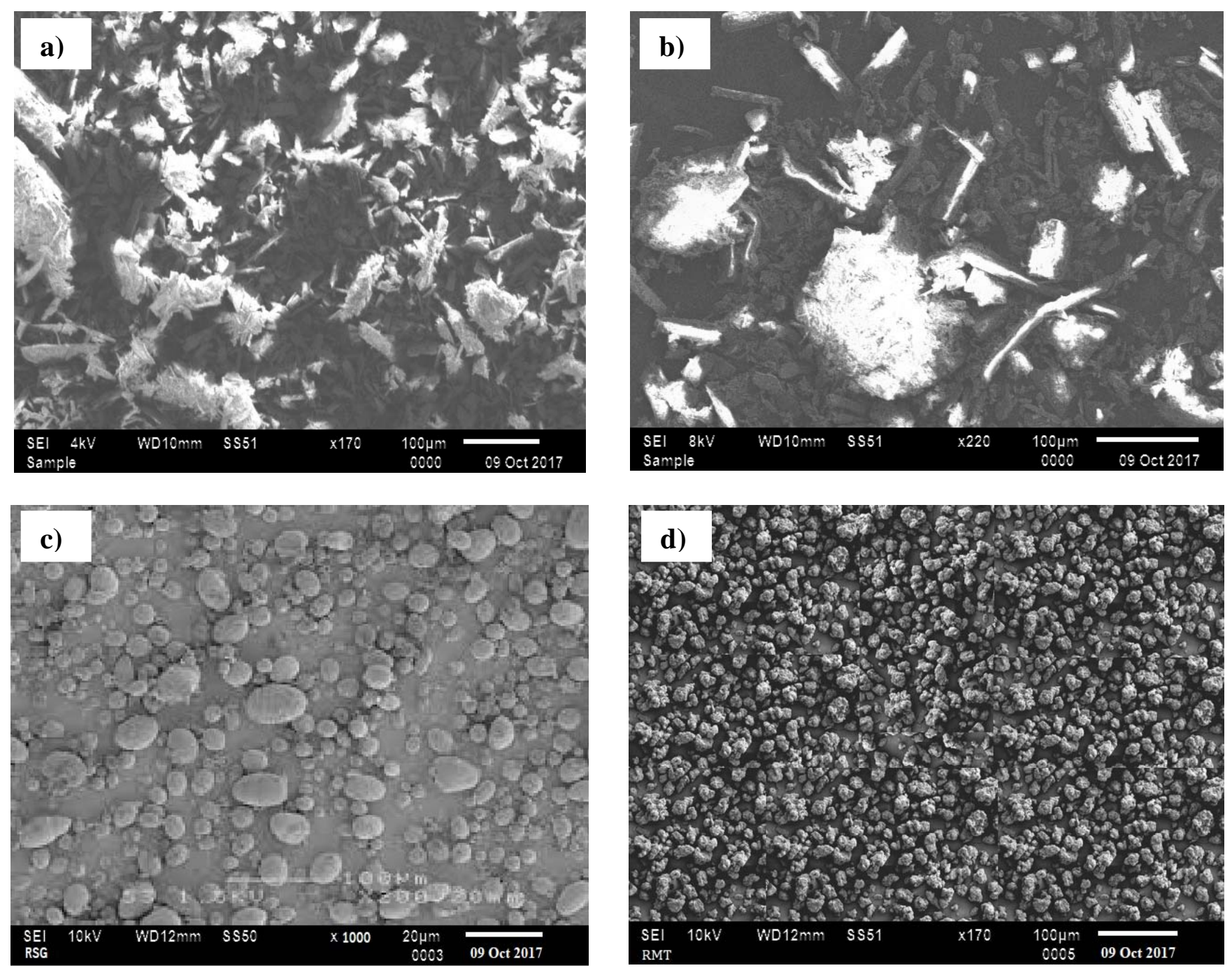

Fig. 5: SEM analysis of a) Famotidine, b) Mannitol, c) Crosspovidone and d) Optimised formulation F8 containing $8 \%$ of crosspovidone

Table 2: Pre-compression properties of prepared formulations

\begin{tabular}{llllll}
\hline Formulation code & Angle of repose & Bulk density $\left(\mathbf{g m} / \mathbf{c m}^{\mathbf{3}}\right)$ & Tapped density $\left(\mathbf{g m} / \mathbf{c m}^{\mathbf{3}}\right)$ & Carr's index & Hausner's ratio \\
\hline F1 & $26.25 \pm 0.64$ & $0.39 \pm 0.03$ & $0.46 \pm 0.24$ & 13.21 & 1.17 \\
F2 & $25.41 \pm 0.48$ & $0.39 \pm 0.12$ & $0.47 \pm 0.19$ & 12.02 & 1.20 \\
F3 & $22.73 \pm 0.46$ & $0.38 \pm 0.09$ & $0.46 \pm 0.24$ & 14.56 & 1.24 \\
F4 & $26.76 \pm 0.32$ & $0.37 \pm 0.17$ & $0.45 \pm 0.12$ & 11.55 & 1.18 \\
F5 & $22.14 \pm 0.66$ & $0.38 \pm 0.15$ & $0.41 \pm 0.14$ & 13.75 & 1.10 \\
F6 & $21.84 \pm 0.89$ & $0.40 \pm 0.16$ & $0.45 \pm 0.16$ & 11.17 & 1.12 \\
F7 & $27.15 \pm 0.42$ & $0.38 \pm 0.12$ & $0.46 \pm 0.21$ & 12.13 & 1.24 \\
F8 & $22.21 \pm 0.36$ & $0.37 \pm 0.16$ & $0.47 \pm 0.18$ & 13.17 & 1.12 \\
F9 & $21.08 \pm 0.32$ & $0.36 \pm 0.14$ & $0.43 \pm 0.12$ & 14.13 & 1.23 \\
\hline
\end{tabular}

All the values are expressed as mean \pm SD where number of experiments $(n=3)$.

\section{Evaluation of post-compression parameters}

\section{Tableting characteristics of the famotidine FDTs}

Prepared tablets were evaluated for weight variation, hardness, friability, wetting time, water absorption ratio, disintegration time and assay and results are given in table 3 and 4 .

All the prepared famotidine FDT are greater than $100 \mathrm{mg}$ and are well within the range of $5 \%$ and hence qualify the test for uniformity of weight. The thickness of all the formulations was in the range of 0.83 to $0.98 \mathrm{~mm}$ and hardness of all the formulations was in the range of 3 to $4 \mathrm{~kg} / \mathrm{cm}^{2}$. The percentage weight loss in the friability test was found to be less than $0.5 \%$ for all the batches.

The wetting time of all the formulations was in the range of 37 to 45 sec. The water absorption ratio of all the formulations was in the range of 83.2 to $99.6 \mathrm{sec}$. The disintegration time of all the formulations was in the range of 85-120 sec. Assay was found to be in the range of 98.94 to $101.29 \%$ of the stated amount of famotidine. Thus, famotidine FDT prepared with the selected superdisintegrants were regarded as good quality fulfilling the official and other requirements of tablets. 
Table 3: Physicochemical properties of the famotidine FDT

\begin{tabular}{|c|c|c|c|c|}
\hline S. No. & Weight variation $\left(\mathrm{kg} / \mathrm{cm}^{2}\right)^{*}$ & Thickness (mm)** & Hardness $\left(\mathrm{kg} / \mathrm{cm}^{2}\right)^{* *}$ & Friability (\%) ${ }^{* * *}$ \\
\hline F1 & $100.08 \pm 0.11$ & $0.83 \pm 0.14$ & $3-4$ & 0.39 \\
\hline $\mathrm{F} 2$ & $101.07 \pm 0.12$ & $0.98 \pm 0.16$ & $3-4$ & 0.42 \\
\hline F3 & $100.17 \pm 0.14$ & $0.92 \pm 0.18$ & $3-4$ & 0.38 \\
\hline F4 & $100.97 \pm 0.13$ & $0.91 \pm 0.24$ & $3-4$ & 0.45 \\
\hline F5 & $100.83 \pm 0.12$ & $0.86 \pm 0.23$ & $3-4$ & 0.37 \\
\hline F6 & $101.01 \pm 0.11$ & 0.9240 .15 & $3-4$ & 0.35 \\
\hline F7 & $100.95 \pm 0.14$ & $0.91 \pm 0.18$ & $3-4$ & 0.42 \\
\hline F8 & $100.21 \pm 0.12$ & $0.89 \pm 0.22$ & $3-4$ & 0.40 \\
\hline F9 & $101.01 \pm 0.18$ & $0.93 \pm 0.15$ & $3-4$ & 0.35 \\
\hline
\end{tabular}

Values are expressed as mean \pm SD where ${ }^{*} \mathrm{n}=20 ;{ }^{* *} \mathrm{n}=5 ;{ }^{* * *} \mathrm{n} \approx 6.5$ gm of total weight.

Table 4: Physicochemical properties of the famotidine FDT

\begin{tabular}{|c|c|c|c|c|}
\hline S. No. & Wetting time (sec)* & Water absorption ratio (\%) & Disintegration time (sec)* & Drug content $(\%)^{* *}$ \\
\hline F1 & $39 \pm 0.14$ & $87.9 \pm 0.41$ & $108 \pm 1.61$ & $99.86 \pm 0.14$ \\
\hline $\mathrm{F} 2$ & $38 \pm 0.16$ & $89.6 \pm 0.25$ & $101 \pm 1.24$ & $99.71 \pm 0.40$ \\
\hline F3 & $41 \pm 0.18$ & $96.2 \pm 0.18$ & $95 \pm 1.22$ & $98.94 \pm 0.68$ \\
\hline F4 & $39 \pm 0.12$ & $95.6 \pm 0.29$ & $85 \pm 1.44$ & $100.07 \pm 0.12$ \\
\hline F5 & $43 \pm 0.22$ & $96.8 \pm 0.36$ & $120 \pm 1.35$ & $99.88 \pm 0.43$ \\
\hline F6 & $37 \pm 0.19$ & $99.5 \pm 0.15$ & $101 \pm 1.32$ & $100.16 \pm 0.15$ \\
\hline F7 & $45 \pm 0.22$ & $83.2 \pm 0.24$ & $116 \pm 1.06$ & $99.27 \pm 0.48$ \\
\hline F8 & $39 \pm 0.15$ & $98.7 \pm 0.39$ & $91 \pm 1.03$ & $101.29 \pm 0.11$ \\
\hline F9 & $37 \pm 0.19$ & $99.6 \pm 0.43$ & $107 \pm 1.32$ & $100.15 \pm 0.13$ \\
\hline
\end{tabular}

Values are expressed as mean \pm SD where ${ }^{*} \mathrm{n}=3 ;{ }^{* *} \mathrm{n}=10$.
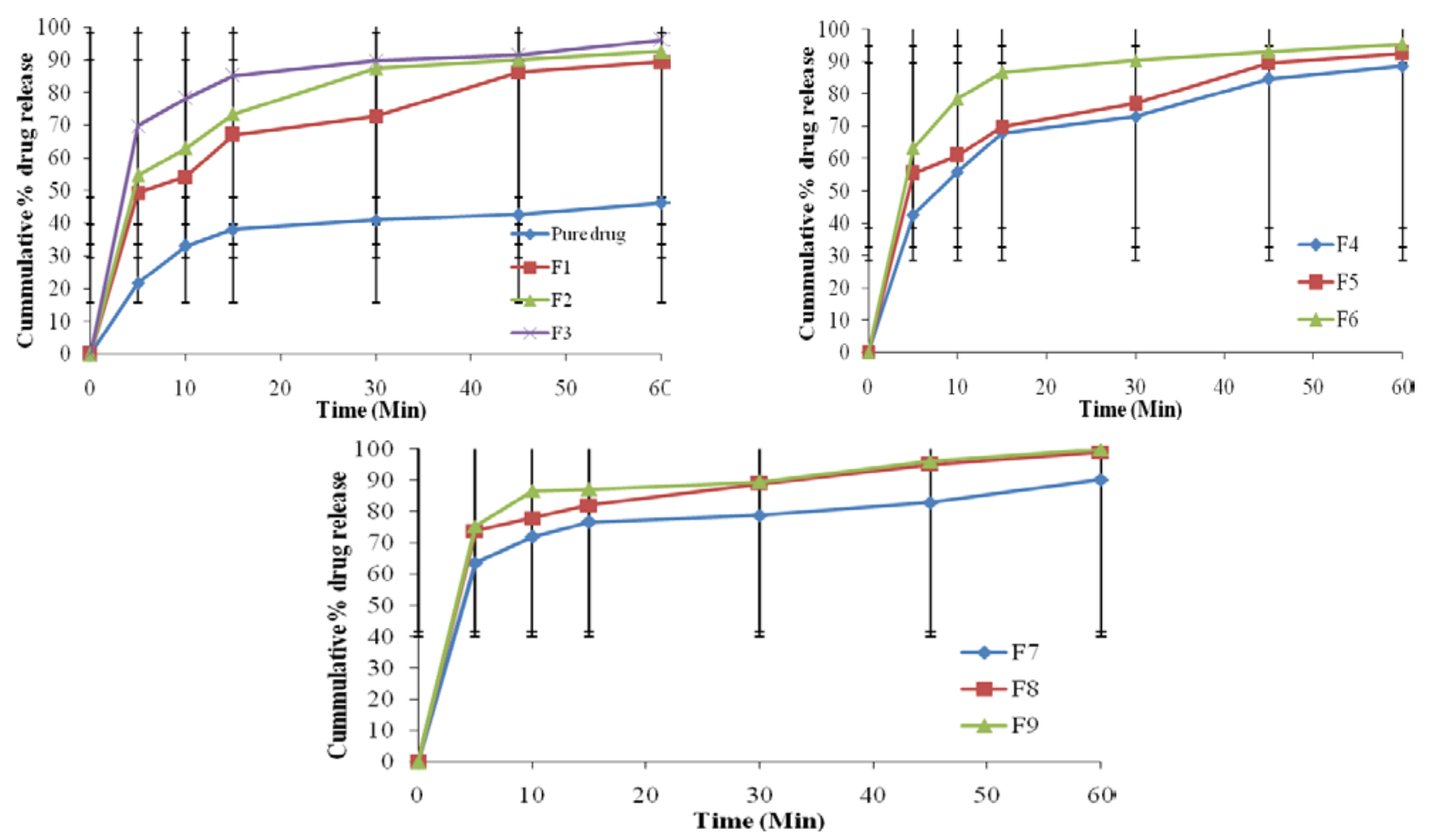

Fig. 6: Cummulative \% drug release of famotidine pure drug and formulations F1 to F9 prepared with synthetic superdisintegrants (n=3, mean \pm SD)

\section{In vitro dissolution studies}

The in vitro dissolution studies of fast dissolving tablets were conducted in simulated gastric fluid $0.1 \mathrm{~N} \mathrm{HCl}$ for $1 \mathrm{~h}$. The results of the drug release studies of all the prepared formulations are shown in fig. 6.

The F1-F9 famotidine FDT formulations prepared with different ratios of synthetic superdisintegrants, have shown release profile similar $>66 \%$ drug release in $1 \mathrm{~h}$.
The drug release from F1, F2 and F3 were composed of sodium starch glycolate $4 \%, 8 \%$ and $12 \%$ was found to be $90.32,94.41$ and $95.04 \%$ in 60 min. The drug release from F4, F5 and F6 were composed of croscarmellose sodium $4 \%, 8 \%$ and $12 \%$ was found to be $85.62,92.47$ and 95.32 in $60 \mathrm{~min}$. The drug release form formulations F7, F8 and F9 were composed of crosspovidone was found to be 79.62, 99.98 and 99.89 in $60 \mathrm{~min}$.

From all the above studies formulation F8 prepared with $8 \%$ of crosspovidone showed more than $70 \%$ and $95 \%$ of drug release 
within 5 min and 1 hour, might be due to low water uptake and more gelling nature of CCS, SSG than CP [20], which is shown to have low swelling efficiency, high water uptake capacity and spongy nature, which yield porous tablets that disintegrate in fraction of seconds. Hence, formulation F8 is selected as the best formulation among all the other formulations.

The in vitro drug release profiles of famitidine were applied on various kinetic models in order to evaluate the mechanism of drug release. The different kinetic models evaluated were zero order, first order, Higuchi, Hixson-Crowell. The data obtained were also put in Korsmeyer-Peppas model in order to find out $n$ value, which describes the drug release mechanism.

All the formulations followed First order release with Fickian mechanism of drug release, due to the dominant erosion pattern, results were given in table 5 . This may be due to the use of synthetic superdisintegrants in these formulations exhibited dominant erosion pattern with burst release of the drug from the formulation.

Table 5: Release kinetics data of famotidine prepared formulations F1 to F9

\begin{tabular}{|c|c|c|c|c|c|c|c|}
\hline $\begin{array}{l}\text { Formulation } \\
\text { code }\end{array}$ & $\begin{array}{l}\text { Zero } \\
\text { order (r) }\end{array}$ & $\begin{array}{l}\text { First } \\
\text { order (r) }\end{array}$ & $\begin{array}{l}\text { Higuchi } \\
\text { (r) }\end{array}$ & $\begin{array}{l}\text { Korsemeyer- } \\
\text { peppas (r) }\end{array}$ & $\begin{array}{l}\text { Hixson- } \\
\text { crowell (r) }\end{array}$ & $\begin{array}{l}\text { Korsemeyer- } \\
\text { peppas (n) }\end{array}$ & $\begin{array}{l}\text { Mechanism of } \\
\text { release }\end{array}$ \\
\hline Pure Drug & 0.609 & 0.682 & 0.855 & 0.866 & 0.658 & 0.269 & Fickian \\
\hline F1 & 0.680 & 0.929 & 0.900 & 0.968 & 0.864 & 0.249 & Fickian \\
\hline $\mathrm{F} 2$ & 0.602 & 0.892 & 0.855 & 0.969 & 0.808 & 0.223 & Fickian \\
\hline F3 & 0.436 & 0.826 & 0.712 & 0.958 & 0.689 & 0.121 & Fickian \\
\hline $\mathrm{F} 4$ & 0.687 & 0.925 & 0.909 & 0.961 & 0.860 & 0.284 & Fickian \\
\hline F5 & 0.635 & 0.932 & 0.870 & 0.981 & 0.856 & 0.214 & Fickian \\
\hline F6 & 0.460 & 0.816 & 0.739 & 0.877 & 0.689 & 0.151 & Fickian \\
\hline F7 & 0.459 & 0.759 & 0.726 & 0.952 & 0.654 & 0.123 & Fickian \\
\hline F8 & 0.472 & 0.945 & 0.738 & 0.981 & 0.825 & 0.124 & Fickian \\
\hline F9 & 0.430 & 0.877 & 0.700 & 0.982 & 0.819 & 0.108 & Fickian \\
\hline
\end{tabular}

\section{Comparative studies}

The famotidine pure drug, optimised formulations F8 with $8 \%$ crosspovidone was compared with the marketed product. The drug release profiles were shown in fig. 7. The drug release was found to be $21.67 \%$ for pure drug in $5 \mathrm{~min}$, where as $54.61 \%$ and $73.82 \%$ for marketed product and optimised formulations F8.

Hence, the in vitro drug release for the optimised formulation F8 was found to be better than the marketed product.

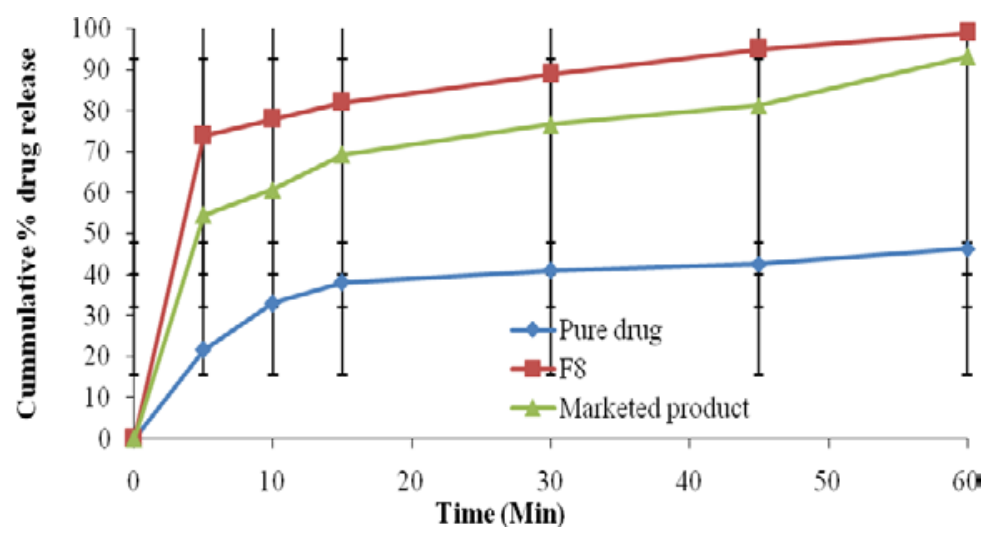

Fig. 7: Cummulative \% drug release of famotidine pure drug, optimised formulations $F 8$ in comparision with marketed product ( $n=3$, mean \pm SD)

\section{CONCLUSION}

The present study was carried out to develop the fast dissolving tablets of famotidine by using various superdisintegrants at different ratios in comparison with marketed product. The formulations prepared with $8 \% \mathrm{w} / \mathrm{w}$ concentration of CP F8 for fast dissolving tablets were found to be more suitable than the formulation prepared with other synthetic superdisintegrants and gave maximum drug release (\%) within $5 \mathrm{~min}$. It was found that the release rate was found to be more influenced by crospovidone superdisintegrant and the concentration of the disintegrant employed in the preparation of the tablets. The optimised formulation F8 drug release with crospovidone is slightly greater than that of the other synthetic superdisintegrant.

\section{ACKNOWLEDGEMENT}

The author Dr. S. Rajeswari is thankful to MANASA's trust and Principal Dr. P. Udaya Shankar, Maharajah's College of Pharmacy,
Phool Baugh, Vizianagaram, India for providing the necessary facilities to carry out this research work. The corresponding author is thankful to M. Yerni Kumari for gathering valuable information to carry out the research work and also assisted in doing the research work.

\section{AUTHORS CONTRIBUTIONS}

All the author have contributed equally

\section{CONFLICTS OF INTERESTS}

All authors have none to declare

\section{REFERENCES}

1. Sutpute MM, Shivaji NT. Formulation and in vitro evaluation of fast dissolving tablets of metoprolol tartrate. Braz J Pharm Sci 2013;49:783-92.

2. Famotidine drug profile. Available from: https:// www.drugbank.ca/drugs/DB00927 [Last accessed on 15 Nov 2017]. 
3. Famotidine drug details. Available from: https:// www.fda.gov/Drugs/InformationOnDrugs/ucm129662.htm. [Last Accessed on 21 Apr 2018]

4. Famotidine drug profile. Available from: https:// pubchem.ncbi.nlm.nih.gov/compound/famotidine\#section=Inf ormation-Sources. [Last accessed on 16 Nov 2017]

5. Rose RSS, Shanmuganathan TRS, Senthil KSR, Thanga TA. Formulation and evaluation of mouth dissolving famotidine tablet. Int J Chem Tech Res 2009;1:1251-6.

6. Venkateswarlu B, Pragati BK, Debjit B. Formulation and evaluation of famotidine fast dissolving tablets by direct compression method. Indian J Res Pharm Biotechnol 2013;1:609-13.

7. Rajeswari S, Sravya K, Murthy KVR. Development, formulation and evaluation of a bilayer gastric retentive floating tablets of ranitidine $\mathrm{HCl}$ and clarithromycin using natural polymers. Int J Pharm Pharm Sci 2017;9:164-77.

8. Vijayanand P, Sridevi P, Bhagavan Raju M. Development and optimization of orodispersible tablets of carvedilol by a combination of super-disintegrants addition and sublimation techniques. Int J Pharm Pharm Sci 2017;9:155-60.

9. Hari K, Rajeswari S, Murthy KVR. Preparation and evaluation of orally disintegrating tablets of drotaverine hydrochloride using sublimation technique. Int J Pharm Pharm Sci 2018;10:85-95.

10. Shah U, Augsburger L. Evaluation of the functional equivance of crospovidone NF from different sources: standard performance test. Pharm Dev Technol 2001;6:419-30.
11. Bhaskaran S, Narmada GV. Orally disintegrating tablets. Indian Pharm 2002;1:9-12.

12. Kaushik D, Dureja H, Saini TR. Mouth dissolving tablets: a review. Indian Drugs 2004;41:187-93.

13. Mishra B, Panigrahi D. Mouth dissolving tablets: an overview of preparation techniques, evaluation and patented technologies. J Pham Res 2005;4:33.

14. Jhansi Rani M, Surendra A, Sudhakar AM, Nagoor A. Formulation and evaluation of domperidone fast dissolving tablets using natural superdisintegrants. Int J Res Pharm Nano Sci 2013;2:152-7.

15. Parmar RB, Baria AH, Tank HM. Formulation and evaluation of domperidone fast dissolving tablets. Int J Pharm Tech Res 2009;1:483-7.

16. Subrahmanyam CVS. Text book of physical pharmaceutics. $2^{\text {nd }}$ Ed. New Delhi: Vallabh Prakashan; 2005. p. 210-28.

17. Lachman L, Lieberman A, Kinig JL. The theory and practice of industrial pharmacy. 2nd ed. Varghese Publishing House; 1999. p. 67-74.

18. Govt. of India, Ministry of health and family welfare. Indian pharmacopoeia 2007. The Indian pharmacopoeia commission, Ghaziabad; 2007;1:177-87.

19. Padmaja B, Ramakrishna R, Goutham G. Formulation and evaluation of fast dissolving tablets of ranitidine hydrochloride. J Pharm Res 2015;9:165-9.

20. Anupama K, Shelly K, Neena B. Formulation and evaluation of mouth dissolving tablets of oxcarbazepine. Int J Pharm Pharm Sci 2009;1:12-23. 